\title{
Structural and optical properties of zinc titanates synthesized by precipitation method
}

\author{
LOKESH BUDIGI $^{\mathrm{a}}$, MADHUSUDHANA RAO NASINA ${ }^{\mathrm{a}, *}$, KALEEMULLA SHAIK $^{\mathrm{a}}$ and \\ SIVAKUMAR AMARAVADI ${ }^{\mathrm{b}}$ \\ ${ }^{a}$ Thin Films Laboratory, Materials Physics Division, School of Advanced Sciences, \\ VIT University, Vellore 632 014, Tamil Nadu, India \\ ${ }^{\mathrm{b}}$ School of Advanced Sciences, VIT University, Vellore 632 014, Tamil Nadu, India \\ e-mail:drnmrao@gmail.com
}

MS received 8 June 2014; revised 30 August 2014; accepted 18 September 2014

\begin{abstract}
Synthesis of zinc titanates was carried out using a simple precipitation method followed by calcination at different temperatures to obtain different phases of the material. The phase transition characteristics, presence of functional groups, structural aspects and optical bandgaps with respect to calcination temperature were studied by thermal analysis, EDAX, FT-IR, powder XRD, Raman and UV-Vis spectroscopy respectively. The compound on heat treatment at $100^{\circ} \mathrm{C}$ for $24 \mathrm{~h}$ showed broadened peaks in XRD. With increasing temperature of calcination, the compound appeared to turn to crystalline phase and cubic $\mathrm{ZnTiO}_{3}$ phase was observed at $600^{\circ} \mathrm{C}$. Partial phase transformation of cubic phase $\mathrm{ZnTiO}_{3}$ into hexagonal ilmenite type $\mathrm{ZnTiO}_{3}$ was observed in the temperature range $700^{\circ} \mathrm{C}$ to $900^{\circ} \mathrm{C}$. At $1000^{\circ} \mathrm{C}$ both cubic and hexagonal ilmenite phases decomposed into cubic phase $\mathrm{Zn}_{2} \mathrm{TiO}_{4}$ and rutile $\mathrm{TiO}_{2}$. FT-IR showed $\mathrm{M}-\mathrm{O}$ bonds in the range of $400 \mathrm{~cm}^{-1}$ to $700 \mathrm{~cm}^{-1}$. Raman spectra of cubic defect spinel $\mathrm{ZnTiO}_{3}$ and cubic inverse spinel $\mathrm{Zn}_{2} \mathrm{TiO}_{4}$ were found to be similar. The optical bandgap calculated using diffuse reflectance spectra was found to be in the range of 3.59 to $3.84 \mathrm{eV}$ depending on calcination temperature.
\end{abstract}

Keywords. Zinc titanate; phase transition; Raman spectroscopy; bandgap; diffuse reflectance spectroscopy.

\section{Introduction}

Zinc titanate metal oxides have attracted considerable attention for use as sorbent for desulfurization of coal gas, ${ }^{1}$ catalyst in liquid phase organic transformations, ${ }^{2}$ dielectric and microwave resonators, ${ }^{3}$ gas sensors, ${ }^{4}$ oxidation of hydrocarbons or $\mathrm{CO}$ and $\mathrm{NO}$ reduction, ${ }^{5}$ semiconductor material, ${ }^{6}$ photocatalytic material, ${ }^{7}$ and also in paints as pigments. ${ }^{8}$ Owing to these properties, several methods have been employed for the synthesis of zinc titanates such as solid state reaction, ${ }^{9-11}$ solgel, ${ }^{12-14}$ Pechini process, ${ }^{15}$ hydrothermal method, ${ }^{16}$ sputtering, ${ }^{17,18}$ microwave heating, ${ }^{19}$ and molten salt method, ${ }^{20}$ etc. In solid-state reactions, formation of end product depends on the calcination temperature, particle size and crystalline phase of starting materials $\mathrm{TiO}_{2}$ and $\mathrm{ZnO}$. Liu et $a l^{21}$ proposed that the formation of $\mathrm{Zn}_{2} \mathrm{TiO}_{4}$ and $\mathrm{Zn}_{2} \mathrm{Ti}_{3} \mathrm{O}_{8}$ are confined to the presence of anatase $\mathrm{TiO}_{2}$, while $\mathrm{ZnTiO}_{3}$ will be formed only in the presence of rutile $\mathrm{TiO}_{2}$ due to structural similarities. On the other hand $\mathrm{Zn}_{2} \mathrm{TiO}_{4}$ could be synthesized by solid state reaction using $\mathrm{ZnO}$ and $\mathrm{TiO}_{2}$ in

\footnotetext{
*For correspondence
}

2:1 molar ratio, while $\mathrm{ZnTiO}_{3}$ could not be synthesized with 1:1 molar ratio of $\mathrm{ZnO}$ and $\mathrm{TiO}_{2}$ due to the narrow phase stability temperature region of $\mathrm{ZnTiO}_{3}$, decomposing it into $\mathrm{Zn}_{2} \mathrm{TiO}_{4}$ and rutile $\mathrm{TiO}_{2}{ }^{22}$ Thus making single phase $\mathrm{ZnTiO}_{3}$ by solid state reaction is difficult. Metal alkoxides are generally used as starting materials in sol-gel synthesis of zinc titanates. Metal alkoxides are moisture sensitive and are easily hydrolysed to form metal hydroxides and their respective alcohols. Sol-gel or microwave assisted sol-gel method requires controlled hydrolysis of metal alkoxides in anhydrous alcohol to get uniform particle size distribution. ${ }^{12-14}$ Further, in sol-gel synthesis there was no consensus on the product obtained at low temperature $\left(<700^{\circ} \mathrm{C}\right)$. Though the starting reagents were taken in 1:1 molar ratio, $\mathrm{Zn}_{2} \mathrm{Ti}_{3} \mathrm{O}_{8}$ was reported as a low temperature form of zinc titanates without accounting for the possible existence of $\mathrm{ZnO}$ to balance the stoichiometry. ${ }^{14,16}$ Studies by Mrazek et al. ${ }^{12}$ have not confirmed the existence of $\mathrm{Zn}_{2} \mathrm{Ti}_{3} \mathrm{O}_{8}$ which on calcination at higher temperatures transforms into $\mathrm{ZnTiO}_{3}$. Thus there is a need to study zinc titanate formation at low temperature. In Pichini process, metal ions were reacted with citric acid ligand to form citric acid metal complexes. These citric acid 
metal complexes were then converted to thick gel by heating around $90^{\circ} \mathrm{C}$ and later combusted to form metal oxides. Finally the combusted products were calcined at high temperature to obtain phase transformation. ${ }^{15}$ Hydrothermal synthesis requires special hydrothermal setup to maintain optimum temperature and pressure. ${ }^{16}$ In sputtering techniques, zinc titanates synthesized by solid state reactions are generally used as targets for thin film coating on various substrates. ${ }^{17,18}$ In molten salt synthesis, ratio of molten salt to oxides is maintained to be very high. After completion of the reaction, final products are obtained by removing molten salts by repeated washing with distilled water. ${ }^{20}$ Compared to the methods mentioned in this paper, precipitation method adopted in this study has a number of advantages such as ease of handling reagents, and zero requirement of special apparatus or solvents. Precipitation reactions can be performed in aqueous media. Apart from maintaining $\mathrm{pH}$ to ensure optimum precipitation of both $\mathrm{Zn}$ and $\mathrm{Ti}$, no special experimental conditions are required.

The main aim of the present study is to synthesize zinc titanates by a simple precipitation method and to study the phase transitions by various characterization techniques, to investigate phase transformation to predict formation of zinc titanium hydroxide $\mathrm{ZnTi}(\mathrm{OH})_{6}$ and to study the low temperature phase of zinc titanates acting as precursors for formation of zinc titanium oxides.

\section{Experimental}

\subsection{Materials and methods}

Anhydrous $\mathrm{ZnCl}_{2}$ powder (99.995\%, Sigma Aldrich), $\mathrm{TiCl}_{3}$ solution $\left(\mathrm{TiCl}_{3}\right.$ minimum $12 \%$ in $\mathrm{HCl}$ solution, Sigma Aldrich) and $\mathrm{NaOH}$ (98.5\%, Sigma Aldrich) were used as starting materials for zinc titanate synthesis. To maintain stoichiometry the amount of Ti present in $\mathrm{TiCl}_{3}$ in $12 \% \mathrm{HCl}$ solution was gravimetrically estimated from the quantity of $\mathrm{TiO}_{2}$ formed. ${ }^{23} 50 \mathrm{~mL}$ of 0.1 mole aqueous $\mathrm{ZnCl}_{2}$ solution and $50 \mathrm{~mL}$ of 0.1 mole $\mathrm{TiCl}_{3}$ in $\mathrm{HCl}$ solution were mixed together to form a violet coloured solution measuring $\mathrm{pH} 1.43$. To this solution, $1 \mathrm{M} \mathrm{NaOH}$ solution was added dropwise till $\mathrm{pH}$ reached 7.0. A dark blue coloured zinc titanium hydroxide precipitate was formed instantaneously. Cassaignon et al. ${ }^{23}$ reported that $\mathrm{TiCl}_{3}$ aqueous solution on reacting with $\mathrm{NaOH}$ solution at $\mathrm{pH}>4.5$ forms air unstable partially oxidized dark blue $\mathrm{Ti}(\mathrm{OH})_{3+x}$ precipitate where $x$ is a fraction indicating the rate of oxidation, and turns white after several hours due to oxidation in atmospheric oxygen. Similarly the dark blue coloured zinc titanium hydroxide precipitate was oxidized by stirring in presence of atmospheric oxygen for $24 \mathrm{~h}$ to form white zinc titanium hydroxide precipitate. This precipitate was washed several times with distilled water and filtered using a suction pump. Filtrate was tested qualitatively for $\mathrm{Zn}^{2+}, \mathrm{Ti}^{3+}$ and $\mathrm{Ti}^{4+}$ ions as per procedure available. ${ }^{24}$ Absence of $\mathrm{Zn}^{2+}$, $\mathrm{Ti}^{3+}$ and $\mathrm{Ti}^{4+}$ in the filtrate solution confirmed the complete precipitation of metal ions as hydroxides. The precipitate was dried at $100^{\circ} \mathrm{C}$ for $24 \mathrm{~h}$, ground to result in soft precursor powders and calcinated in a silicon carbide furnace at a heating rate of $4^{\circ} \mathrm{C} / \mathrm{min}$ in the temperature range $100^{\circ} \mathrm{C}$ to $1000^{\circ} \mathrm{C}$ for $2 \mathrm{~h}$ each and gradually cooled to room temperature to form zinc titanates of different phases.

\subsection{Characterization}

TGA-DTA experiments were carried out using SDT Q600 V20.9 instrument in DSC-TGA standard module in nitrogen atmosphere at a gas flow rate of $100 \mathrm{~mL} / \mathrm{min}$ at a heating rate of $4^{\circ} \mathrm{C} / \mathrm{min}$ using $18 \mathrm{mg}$ of the precursor sample to understand the changes in composition. The thermal analysis was carried from room temperature to $600^{\circ} \mathrm{C}$, using alumina cups as sample holders and alumina powder as reference. Elemental analyses of the samples were carried out using FEI Quanta FEG 250 Scanning Electron Microscope (SEM) equipped with EDAX Apollo $\mathrm{X}$ for energy dispersive $\mathrm{X}$-ray spectroscopy. The crystalline structure of the samples was determined by powder XRD using BRUKER D8 Advance X-ray diffractometer using $\mathrm{CuK}_{\alpha}$ radiation $(\lambda=0.15406 \mathrm{~nm})$. The diffraction pattern was recorded with scanning rate of $2 \% \mathrm{~min}$ and step size of $0.02^{\circ}$ ranging from $10^{\circ}$ to $80^{\circ}$. FT-IR spectra were recorded using $\mathrm{KBr}$ pellet method on Shimadzu IR affinity spectrophotometer in the range from $4000 \mathrm{~cm}^{-1}$ to 400 $\mathrm{cm}^{-1}$. Raman spectra were recorded with LABRAM HR 800 micro Raman spectrometer with a laser excitation wavelength of $633 \mathrm{~nm}$ laser. UV-Vis spectra were recorded in diffuse reflectance mode $(\mathrm{R})$ on a JASCO UV-Vis NIR V670 spectrophotometer, using $\mathrm{BaSO}_{4}$ as reference.

\section{Results and Discussion}

\subsection{Thermal analysis}

TGA and DTA curves of the precursor powders heated in nitrogen atmosphere at a rate of $4^{\circ} \mathrm{C} / \mathrm{min}$ using alumina powder as the reference are shown in the figure 1. During precipitation, synthesis, zinc and titanium hydroxides were observed to have formed as shown in equations 1 and 2. From the thermal analysis, 
the observed weight loss could be attributed only to loss of water through thermal decomposition of hydroxide groups and formation of oxide products from the tentative $\mathrm{ZnTi}(\mathrm{OH})_{6}$ hydroxides as shown in equations 3 and 4 . A total weight loss of $27.83 \%$ was observed when the temperature was increased from $\mathrm{RT}$ to $250^{\circ} \mathrm{C}$ which is in agreement with the theoretical weight loss of $25.10 \%$ due to formation of amorphous $\mathrm{Zn}_{2} \mathrm{Ti}_{3} \mathrm{O}_{8}$ and $\mathrm{ZnO}$ as can be anticipated from equation 3 .

$$
\begin{aligned}
& \mathrm{ZnCl}_{2}+\mathrm{TiCl}_{3}+5 \mathrm{NaOH} \longrightarrow \mathrm{Zn}(\mathrm{OH})_{2} \downarrow+\mathrm{Ti}(\mathrm{OH})_{3+x} \downarrow+5 \mathrm{NaCl} \quad x=\text { fraction indicating } \\
& \text { rate of oxidation. } \\
& \mathrm{Zn}(\mathrm{OH})_{2} \downarrow+\mathrm{Ti}(\mathrm{OH})_{3+x} \downarrow \frac{\text { oxidation in presence }}{\text { of atmospheric oxygen }} \mathrm{ZnTi}(\mathrm{OH})_{6} \downarrow \\
& 3 \mathrm{ZnTi}(\mathrm{OH})_{6} \stackrel{-9 \mathrm{H}_{2} \mathrm{O}}{\longrightarrow} \mathrm{Zn}_{2} \mathrm{Ti}_{3} \mathrm{O}_{8}+\mathrm{ZnO} \\
& \mathrm{Zn}_{2} \mathrm{Ti}_{3} \mathrm{O}_{8}+\mathrm{ZnO} \longrightarrow 3 \mathrm{ZnTiO}_{3}
\end{aligned}
$$

EDAX spectra of the uncalcined zinc titanium hydroxide (figure 2a) shows that $\mathrm{Zn}, \mathrm{Ti}$ and $\mathrm{O}$ are present in 30.97, 22.32 and $46.71 \%$ and samples calcined at $600^{\circ} \mathrm{C}$ (figure 2b) showed 40.45, 28.72 and $30.83 \%$ as atomic percentages which correspond to the empirical formulae $\mathrm{ZnTiO}_{6}$ and $\mathrm{ZnTiO}_{3}$, respectively while hydrogen was not detected because of lower atomic mass (EDAX can detect elements only from carbon onwards). From the method adopted it is apparent that hydroxides are expected and the empirical formula $\mathrm{ZnTiO}_{6}$ obtained from EDAX may be due to the tentative zinc titanium hydroxide $\mathrm{ZnTi}(\mathrm{OH})_{6}$. This result is similar to the dehydration of $\mathrm{CuSn}(\mathrm{OH})_{6}$ and other $\mathrm{AB}(\mathrm{OH})_{6}$ hydroxides to form $\mathrm{CuSnO}_{3}$ and $\mathrm{ABO}_{3}$ oxides as described by Zhong et al. ${ }^{25}$ and Chamberland and Silverman. ${ }^{26}$ A weight loss of $2.73 \%$ was observed during the crystallization and formation of cubic $\mathrm{ZnTiO}_{3}$ from amorphous $\mathrm{Zn}_{2} \mathrm{Ti}_{3} \mathrm{O}_{8}$ and $\mathrm{ZnO}$ in the temperature range of $250^{\circ} \mathrm{C}$ to $600^{\circ} \mathrm{C}$. Two endothermic peaks observed at $220^{\circ} \mathrm{C}$ and $320^{\circ} \mathrm{C}$ can be attributed to the partial decomposition of $\mathrm{ZnTi}(\mathrm{OH})_{6}$ precursor to anatase $\mathrm{TiO}_{2}$ and $\mathrm{ZnO}$ as seen in XRD patterns of samples calcined at $200^{\circ} \mathrm{C}$ and $300^{\circ} \mathrm{C}$ respectively. This result is similar to the decomposition of $\mathrm{CuSn}(\mathrm{OH})_{6}$, $\mathrm{ZnSn}(\mathrm{OH})_{6}$ and $\mathrm{CdSn}(\mathrm{OH})_{6}$ and formation of amorphous $\mathrm{CuSnO}_{3}, \mathrm{ZnSnO}_{3}$ and $\mathrm{CdSnO}_{3}$ respectively. ${ }^{26-28}$ An exothermic peak was observed at $415^{\circ} \mathrm{C}$ indicating the formation of amorphous zinc titanate which crystallized to $\mathrm{Zn}_{2} \mathrm{Ti}_{3} \mathrm{O}_{8}$ at $500^{\circ} \mathrm{C}$ as observed in the powder XRD pattern.

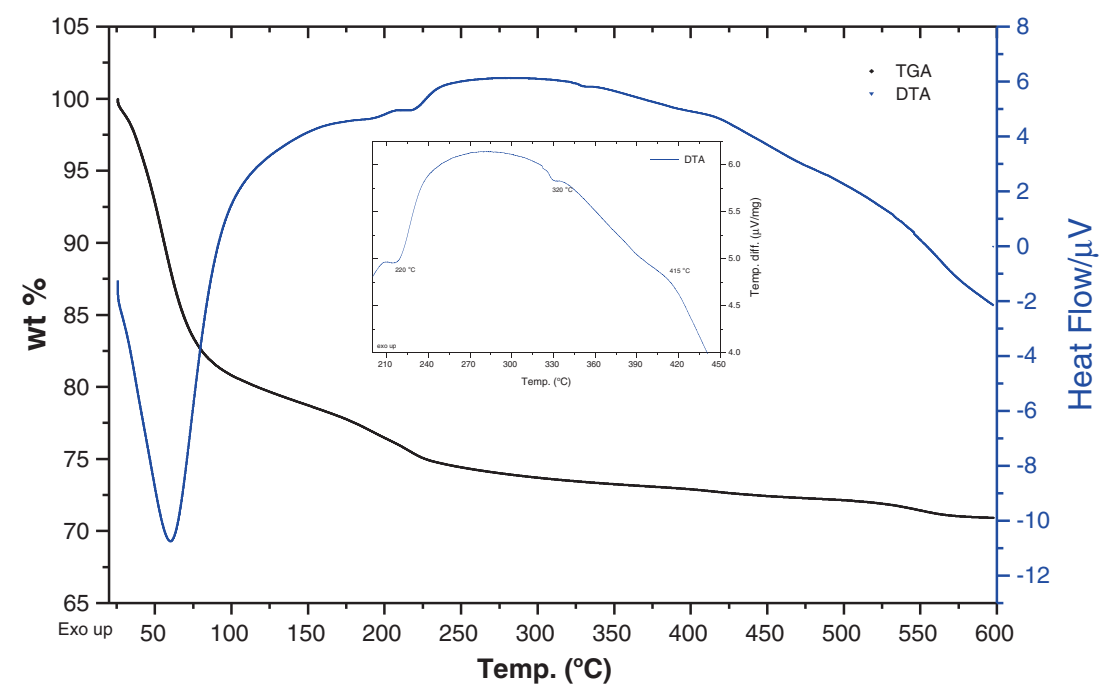

Figure 1. TGA-DTA curves of as synthesized zinc titanate powders. 

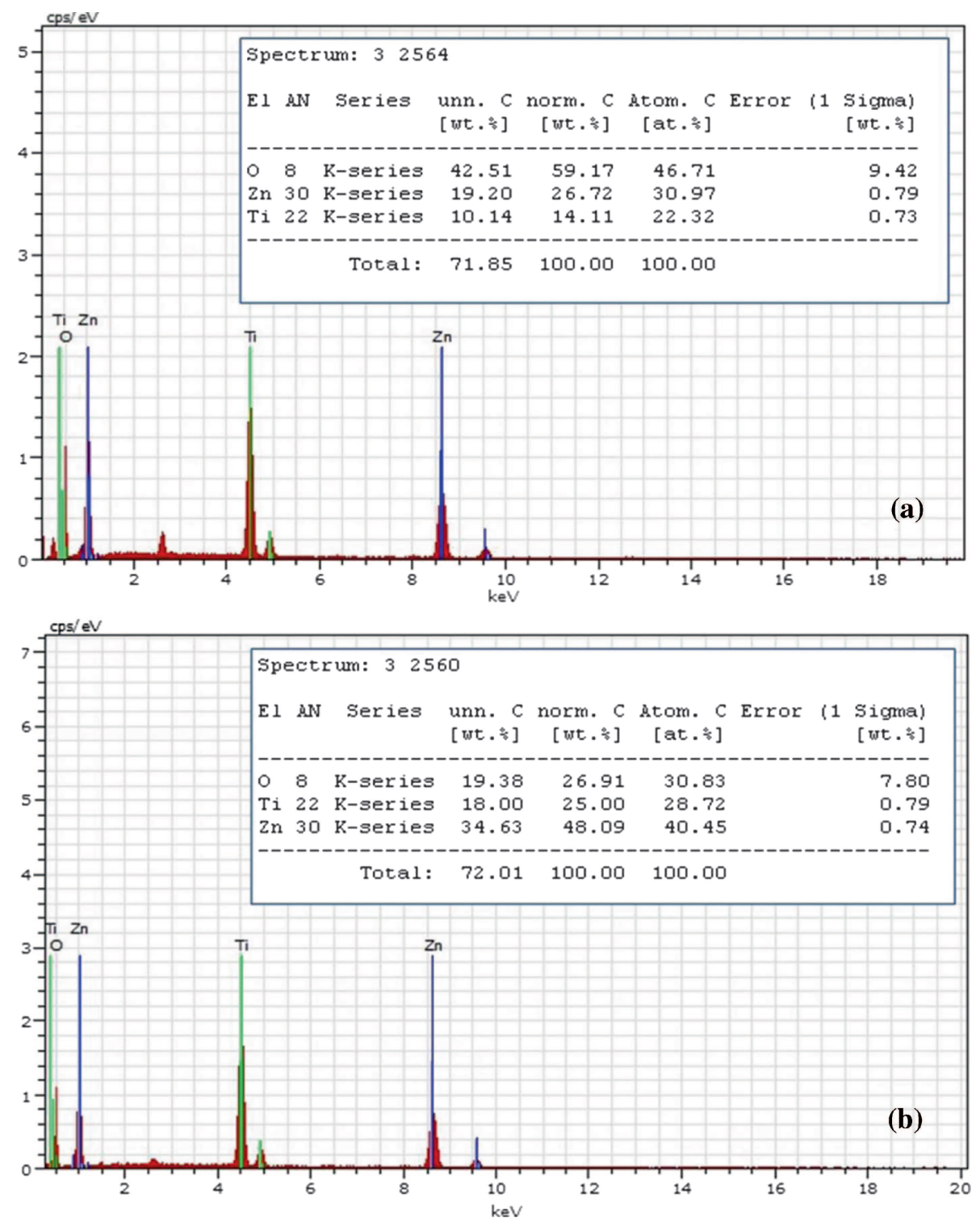

Figure 2. EDAX spectra of, (a) uncalcined zinc titanium hydroxide and (b) calcined at $600^{\circ} \mathrm{C} / 2 \mathrm{~h}$. Inset: EDAX elemental composition.

\subsection{Powder XRD}

XRD pattern of the as-synthesized precursor powder indicates that the sample is amorphous with two broad peaks at $2 \theta \sim 32^{\circ}$ and $\sim 60^{\circ}$. Neither $\mathrm{ZnO}$ nor $\mathrm{TiO}_{2}$ phases were observed (figure $3 \mathrm{a}$ ). It was observed that during synthesis of $\mathrm{ZnO}$ and $\mathrm{TiO}_{2}$ from $\mathrm{ZnCl}_{2}$ and $\mathrm{TiCl}_{3}$ separately under identical conditions $\mathrm{ZnO}$ were found to be crystalline at room temperature, while $\mathrm{TiO}_{2}$ crystallized on calcination. ${ }^{23}$ Absence of $\mathrm{ZnO}$ in the assynthesized sample powders and absence of $\mathrm{Zn}^{2+}, \mathrm{Ti}^{3+}$ or $\mathrm{Ti}^{4+}$ in the filtrate suggests that $\mathrm{Zn}$ and $\mathrm{Ti}$ taken in 1:1 mole ratio were completely precipitated to form a tentative $\mathrm{ZnTi}(\mathrm{OH})_{6}$ or $\mathrm{ZnTiO}_{3} \cdot 3 \mathrm{H}_{2} \mathrm{O}$ type ternary metal oxide precursor. On heating them at $100^{\circ} \mathrm{C}$ for $24 \mathrm{~h}$, a crystalline phase with three broad XRD peaks at $2 \theta 29.10^{\circ}, 48.05^{\circ}$ and $57.05^{\circ}$ is seen to have formed (figure $3 b$ ). To the best of our knowledge no crystalline phase was reported so far in zinc titanate system at temperatures as low as $100^{\circ} \mathrm{C}$. Further investigation is needed to identify the precise crystal structure of the newly formed crystalline phase. On further calcination at $200^{\circ} \mathrm{C}$ for $2 \mathrm{~h}$, an amorphous phase is seen to have formed (figure $3 \mathrm{c}$ ). This is comparable with the decomposition of crystalline $\mathrm{CuSn}(\mathrm{OH})_{6}$ and $\mathrm{BaSn}(\mathrm{OH})_{6}$ in to amorphous phases which on subsequent calcination at higher temperatures crystallize to $\mathrm{CuSnO}_{3}$ and $\mathrm{BaSnO}_{3}$ respectively. ${ }^{25,29}$ Similarly, Chamberland and Silverman reported the formation of $\mathrm{ABO}_{3}$ products from $\mathrm{AB}(\mathrm{OH})_{6}$ derivatives where $\mathrm{A}$ is an alkaline earth metal and $\mathrm{B}$ is either $\mathrm{Sn}$ or $\mathrm{Ir}$ or Os or $\mathrm{Pt}^{26}$ On increasing the calcination temperature to $300^{\circ} \mathrm{C}$ 


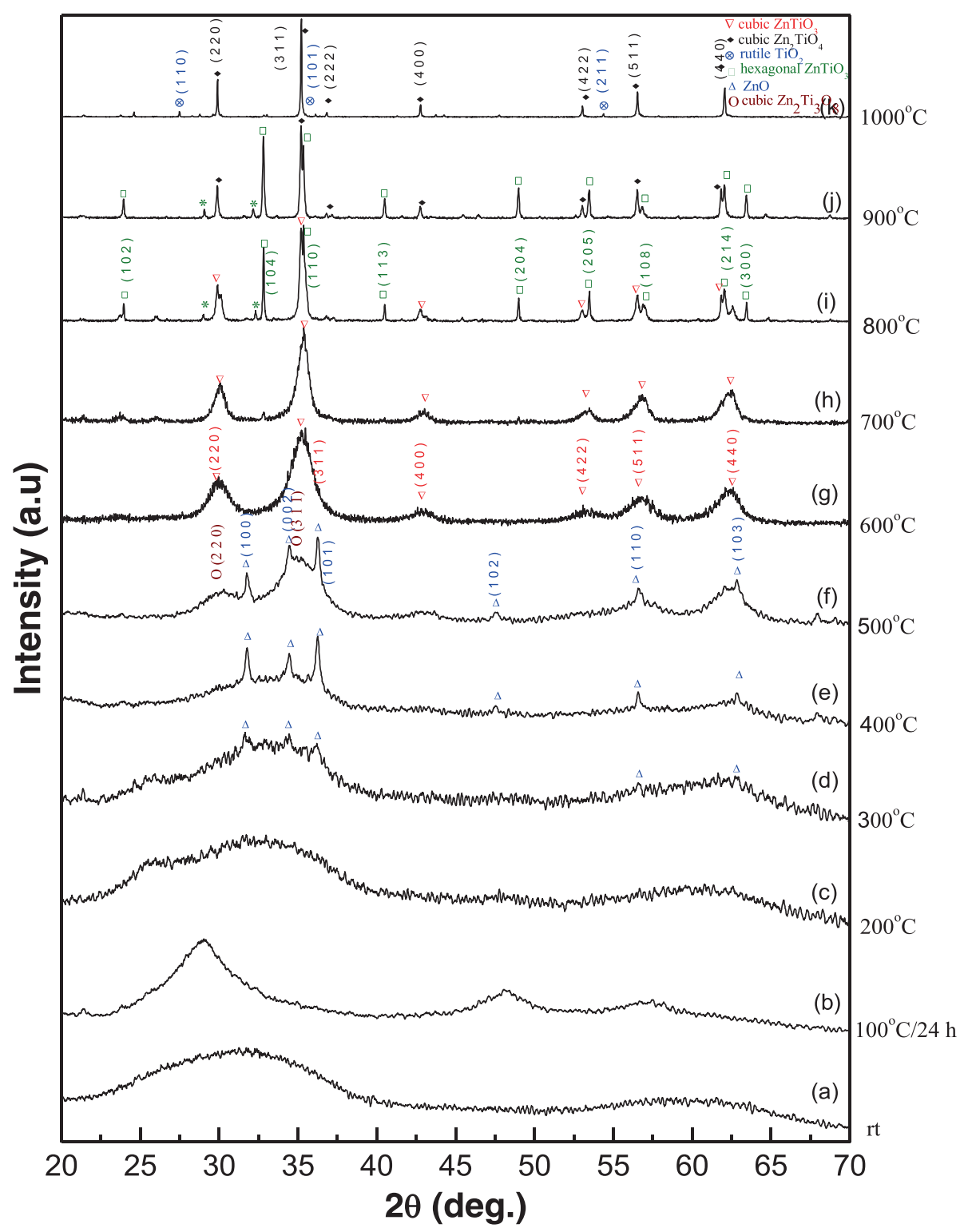

Figure 3. Powder XRD pattern of assynthesized and samples calcined at different temperatures, each for $2 \mathrm{~h}$.

(figure 3d) three low intensity peaks corresponding to ( $\left.\begin{array}{lll}1 & 0 & 0\end{array}\right),\left(\begin{array}{lll}0 & 0 & 2\end{array}\right)$ and ( $\left(\begin{array}{lll}1 & 0 & 1\end{array}\right)$ planes of $\mathrm{ZnO}$ were observed and their intensity increased on calcination at $400^{\circ} \mathrm{C}$ (figure $3 \mathrm{e}$ ) indicating crystallization of $\mathrm{ZnO}$. On calcination at $500^{\circ} \mathrm{C}$ for $2 \mathrm{~h}$ (figure $\left.3 \mathrm{f}\right)(220),(311)$ and (4 00 ) peaks of cubic phase $\mathrm{Zn}_{2} \mathrm{Ti}_{3} \mathrm{O}_{8}$ appeared along with $\mathrm{ZnO} . \mathrm{Zn}_{2} \mathrm{Ti}_{3} \mathrm{O}_{8}$ is a thermodynamically stable compound having defect spinel structure represented as $\mathrm{Zn}_{2-\mathrm{x}} \square_{\mathrm{x}}\left[\mathrm{Zn}_{\mathrm{x}} \square_{1-\mathrm{x}} \mathrm{Ti}_{3}\right] \mathrm{O}_{8}$ where $0 \leq \mathrm{x} \leq 1$ (symbol $\square$ represents unoccupied sites). ${ }^{9,30}$ Here it could be noted that during wet chemical synthesis of zinc titanates, though starting materials $\mathrm{Zn}$ and $\mathrm{Ti}$ cations were taken in 1:1 mole ratio, the crystalline phase observed around $500^{\circ} \mathrm{C}$ to $600^{\circ} \mathrm{C}$ was considered as cubic phase $\mathrm{Zn}_{2} \mathrm{Ti}_{3} \mathrm{O}_{8}$ in which $\mathrm{Zn}$ and $\mathrm{Ti}$ were in 2:3 mole ratio without accounting for another 1 mole of $\mathrm{Zn} .^{13,16,31,32}$ Solubility of $\mathrm{ZnO}$ in $\mathrm{Zn}_{2} \mathrm{Ti}_{3} \mathrm{O}_{8}$ is not reported in literature. ${ }^{9,30}$ It is difficult to differentiate cubic phase $\mathrm{ZnTiO}_{3}$ and cubic phase $\mathrm{Zn}_{2} \mathrm{Ti}_{3} \mathrm{O}_{8}$ because they have similar crystal structure and lattice parameters. ${ }^{11}$ In samples calcined at $500^{\circ} \mathrm{C}$ the possibility of cubic phase $\mathrm{ZnTiO}_{3}$ can be ruled out by the presence of $\mathrm{ZnO}$. At $600^{\circ} \mathrm{C}$ (figure $3 \mathrm{~g}$ ) $\mathrm{ZnO}$ and cubic phase $\mathrm{Zn}_{2} \mathrm{Ti}_{3} \mathrm{O}_{8}$ undergo solid state reaction to form cubic phase $\mathrm{ZnTiO}_{3}$. On increasing the calcination temperature from $600^{\circ} \mathrm{C}$ to $700^{\circ} \mathrm{C}$ (figure $3 \mathrm{~h}$ ) crystallinity of cubic phase $\mathrm{ZnTiO}_{3}$ increases as evidenced from the increased intensities of (2 20$)$ peak at

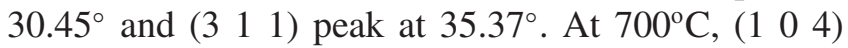
peak appeared at $2 \theta$ of $32.82^{\circ}$ indicating the formation of hexagonal ilmenite phase $\mathrm{ZnTiO}_{3}$ (figure $3 \mathrm{~h}$ ). Further at $800^{\circ} \mathrm{C}$ (figure 3i) $\left(31\right.$ 1) peak of cubic $\mathrm{ZnTiO}_{3}$ split into two peaks corresponding to the $\left(\begin{array}{lll}3 & 1 & 1\end{array}\right)$ and 
(1 110 ) peaks of cubic $\mathrm{ZnTiO}_{3}$ and hexagonal ilmenite $\mathrm{ZnTiO}_{3}$ respectively and their intensities were seen to increase on calcination till $900^{\circ} \mathrm{C}$ (figure $3 \mathrm{j}$ ). This indicates the partial phase transformation of cubic phase $\mathrm{ZnTiO}_{3}$ to hexagonal ilmenite $\mathrm{ZnTiO}_{3}$ and their coexistence in the temperature range of $700^{\circ} \mathrm{C}$ to $900^{\circ} \mathrm{C}$. In the calcination temperature range $700^{\circ} \mathrm{C}$ to $900^{\circ} \mathrm{C}$, it is difficult to distinguish between cubic $\mathrm{ZnTiO}_{3}$, hexagonal ilmenite $\mathrm{ZnTiO}_{3}$ and cubic $\mathrm{Zn}_{2} \mathrm{TiO}_{4}$ because the cubic phase $\mathrm{ZnTiO}_{3}\left(\begin{array}{lll}3 & 1 & 1\end{array}\right)$ and (2 20 ) peaks, the cubic phase $\mathrm{Zn}_{2} \mathrm{TiO}_{4}\left(\begin{array}{lll}3 & 1 & 1\end{array}\right)$ and (2 20 ) peaks and hexagonal $\left(\begin{array}{lll}1 & 1 & 0\end{array}\right)$ peaks appear in a narrow $2 \theta$ range and overlap each other. ${ }^{11}$ At $1000^{\circ} \mathrm{C}$ (figure $3 \mathrm{k}$ ) both cubic and hexagonal ilmenite phase $\mathrm{ZnTiO}_{3}$ is completely decomposed to cubic $\mathrm{Zn}_{2} \mathrm{TiO}_{4}$ and rutile $\mathrm{TiO}_{2}$. The overall sequence of crystallization of zinc titanates and phase evolution with respect to calcination temperature can be tentatively represented as follows:

$$
\begin{aligned}
& 3 \mathrm{ZnTi}(\mathrm{OH})_{6} \longrightarrow 400^{\circ} \mathrm{C} \longrightarrow \mathrm{Zn}_{2} \mathrm{Ti}_{3} \mathrm{O}_{8} \text { (amorphous) }+\mathrm{ZnO} \\
& \mathrm{Zn}_{2} \mathrm{Ti}_{3} \mathrm{O}_{8} \text { (amorphous) }+\mathrm{ZnO} \stackrel{400{ }^{\circ} \mathrm{C}-500{ }^{\circ} \mathrm{C}}{\longrightarrow} \mathrm{Zn}_{2} \mathrm{Ti}_{3} \mathrm{O}_{8} \text { (cubic) }+\mathrm{ZnO} \\
& \mathrm{Zn}_{2} \mathrm{Ti}_{3} \mathrm{O}_{8} \text { (cubic) }+\mathrm{ZnO} \stackrel{600{ }^{\circ} \mathrm{C}-700{ }^{\circ} \mathrm{C}}{\longrightarrow} 3 \mathrm{ZnTiO}_{3} \text { (cubic) } \\
& 3 \mathrm{ZnTiO}_{3} \text { (cubic) } \underset{700{ }^{\circ} \mathrm{C}-900^{\circ} \mathrm{C}}{\longrightarrow} 2 \mathrm{ZnTiO}_{3} \text { (cubic) }+\mathrm{ZnTiO}_{3} \text { (hexagonal) } \\
& 2 \mathrm{ZnTiO}_{3} \text { (cubic) }+\mathrm{ZnTiO}_{3} \text { (hexagonal) } \stackrel{>900^{\circ} \mathrm{C}}{\longrightarrow} 1.5 \mathrm{Zn}_{2} \mathrm{TiO}_{4}(\text { cubic })+1.5 \mathrm{TiO}_{2} \text { (rutile) }
\end{aligned}
$$

\subsection{FT-IR spectra}

FT-IR spectra of the zinc titanates are as shown in the figure 4. As-synthesized samples dried at $100^{\circ} \mathrm{C}$ for $24 \mathrm{~h}$ exhibited a broad peak at $\sim 3434 \mathrm{~cm}^{-1}$ corresponding to the $\mathrm{O}-\mathrm{H}$ stretching and a small sharp peak at $\sim 1631 \mathrm{~cm}^{-1}$ are $\mathrm{H}-\mathrm{O}-\mathrm{H}$ bending mode vibrations of the adsorbed water molecules. The bands at $\sim 2361$ $\mathrm{cm}^{-1}$ were due to asymmetric stretching of $\mathrm{CO}_{2}$ from the atmospheric air. The symmetric and asymmetric stretching of C-O bonds were observed at $\sim 1080 \mathrm{~cm}^{-1}$ and $\sim 1040 \mathrm{~cm}^{-1}$ respectively. ${ }^{33,34}$ The intensities of O-H stretching $\left(\sim 3434 \mathrm{~cm}^{-1}\right)$, H-O-H bending $(\sim 1631$ $\left.\mathrm{cm}^{-1}\right)$ and the symmetric $\left(\sim 1080 \mathrm{~cm}^{-1}\right)$ and asymmetric $\left(\sim 1040 \mathrm{~cm}^{-1}\right) \mathrm{C}-\mathrm{O}$ bands were seen to reduce gradually with increasing calcination temperature and completely disappear $\sim 700^{\circ} \mathrm{C}$ indicating the complete dehydration of the zinc titanate precursors $\mathrm{ZnTi}(\mathrm{OH})_{6}$ or $\mathrm{ZnTiO}_{3} 3 \mathrm{H}_{2} \mathrm{O}$ to form $\mathrm{ZnTiO}_{3}$ as confirmed from the XRD patterns. With an increase in calcination temperature, the intensities of the characteristic vibrations of $\mathrm{TiO}_{6}$ octahedra between $400 \mathrm{~cm}^{-1}$ and $700 \mathrm{~cm}^{-1}$ becomes stronger. ${ }^{35}$ The peaks at $\sim 640 \mathrm{~cm}^{-1}$ and $\sim 530 \mathrm{~cm}^{-1}$ may be due to Ti-O stretching vibrations, ${ }^{24}$ peaks at $\sim 619 \mathrm{~cm}^{-1}$ and $\sim 432 \mathrm{~cm}^{-1}$ corresponding to the stretching vibrations for the Ti-O and $\mathrm{Zn}-\mathrm{O}$ bonds. ${ }^{2}$ A characteristic band at $735 \mathrm{~cm}^{-1}$ appeared at $600^{\circ} \mathrm{C}$, and its absorbance is seen to increase rapidly up to $800^{\circ} \mathrm{C}$ and then decrease gradually till $1000^{\circ} \mathrm{C}$. This can be assigned to the $\mathrm{Zn}-\mathrm{O}-\mathrm{Ti}$ bond structure in cubic $\mathrm{ZnTiO}_{3}$ which is formed at $600^{\circ} \mathrm{C}$, remains as a major phase up to $800^{\circ} \mathrm{C}$ and disappears gradually due to decomposition in to $\mathrm{Zn}_{2} \mathrm{TiO}_{4}$ and $\mathrm{TiO}_{2}$ at $1000^{\circ} \mathrm{C}$ as observed from the respective XRD patterns.

\subsection{Raman spectroscopy}

The Raman spectra of zinc titanates calcined at $100^{\circ} \mathrm{C}$, $200^{\circ} \mathrm{C}$ and $400^{\circ} \mathrm{C}$ are shown in figure 5. No Raman peaks corresponding to neither $\mathrm{ZnO}$ nor $\mathrm{TiO}_{2}$ were observed in samples calcined at $100^{\circ} \mathrm{C}$ and $200^{\circ} \mathrm{C}$. In samples calcined at $400^{\circ} \mathrm{C}$, Raman peaks were observed at $437 \mathrm{~cm}^{-1}$ and $581 \mathrm{~cm}^{-1}$ corresponding to the $E_{2}$ and $\mathrm{E}_{1}$ modes of $\mathrm{ZnO}^{36}$ (figure 5c) which is consistent with $\mathrm{ZnO}$ phase observed in the XRD pattern (figure $3 \mathrm{e}$ ).

The Raman spectra of zinc titanates calcined at 600 , 800 and $1000^{\circ} \mathrm{C}$ are shown in figure 6 . In $800^{\circ} \mathrm{C}$ calcined sample (figure 6b), Raman peaks corresponding to hexagonal ilmenite $\mathrm{ZnTiO}_{3}$ were observed at $263 \mathrm{~cm}^{-1}\left[v_{4}(\mathrm{LO})\right], 341 \mathrm{~cm}^{-1}$ [v $\left.v_{2}(\mathrm{LO}, \mathrm{TO})\right], 530 \mathrm{~cm}^{-1}$ [v $\left.v_{1}(\mathrm{TO})\right]$ and $709 \mathrm{~cm}^{-1}\left[v_{1}(\mathrm{LO})\right]$ along with cubic $\mathrm{ZnTiO}_{3}{ }^{13}$ Raman peaks at $260 \mathrm{~cm}^{-1}\left(\mathrm{~F}_{2 \mathrm{~g}}\right), 306 \mathrm{~cm}^{-1}$ $\left(\mathrm{E}_{\mathrm{g}}\right), 342 \mathrm{~cm}^{-1}\left(\mathrm{~F}_{2 \mathrm{~g}}\right)$ and $733 \mathrm{~cm}^{-1}\left(\mathrm{~A}_{1 \mathrm{~g}}\right)$ modes were assigned to cubic $\mathrm{Zn}_{2} \mathrm{TiO}_{4}{ }^{37}$ and peaks observed at 


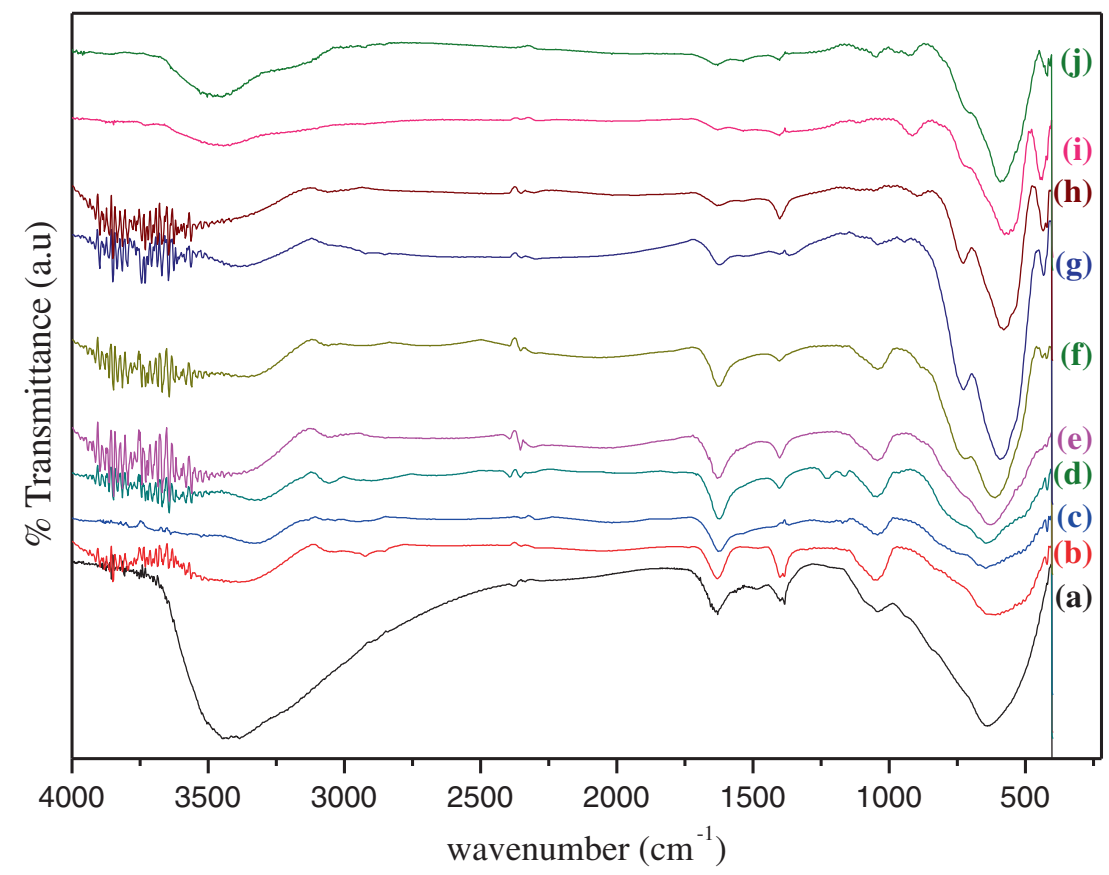

Figure 4. FT-IR spectra of the zinc titanate calcined at (a) $100^{\circ} \mathrm{C} / 24 \mathrm{~h}$, (b) $200^{\circ} \mathrm{C}$, (c) $300^{\circ} \mathrm{C}$, (d) $400^{\circ} \mathrm{C}$, (e) $500^{\circ} \mathrm{C}$, (f) $600^{\circ} \mathrm{C}$; (g) $700^{\circ} \mathrm{C}$, (h) $800^{\circ} \mathrm{C}$, (i) $900^{\circ} \mathrm{C}$, and (j) $1000^{\circ} \mathrm{C}$ for $2 \mathrm{~h}$ each.

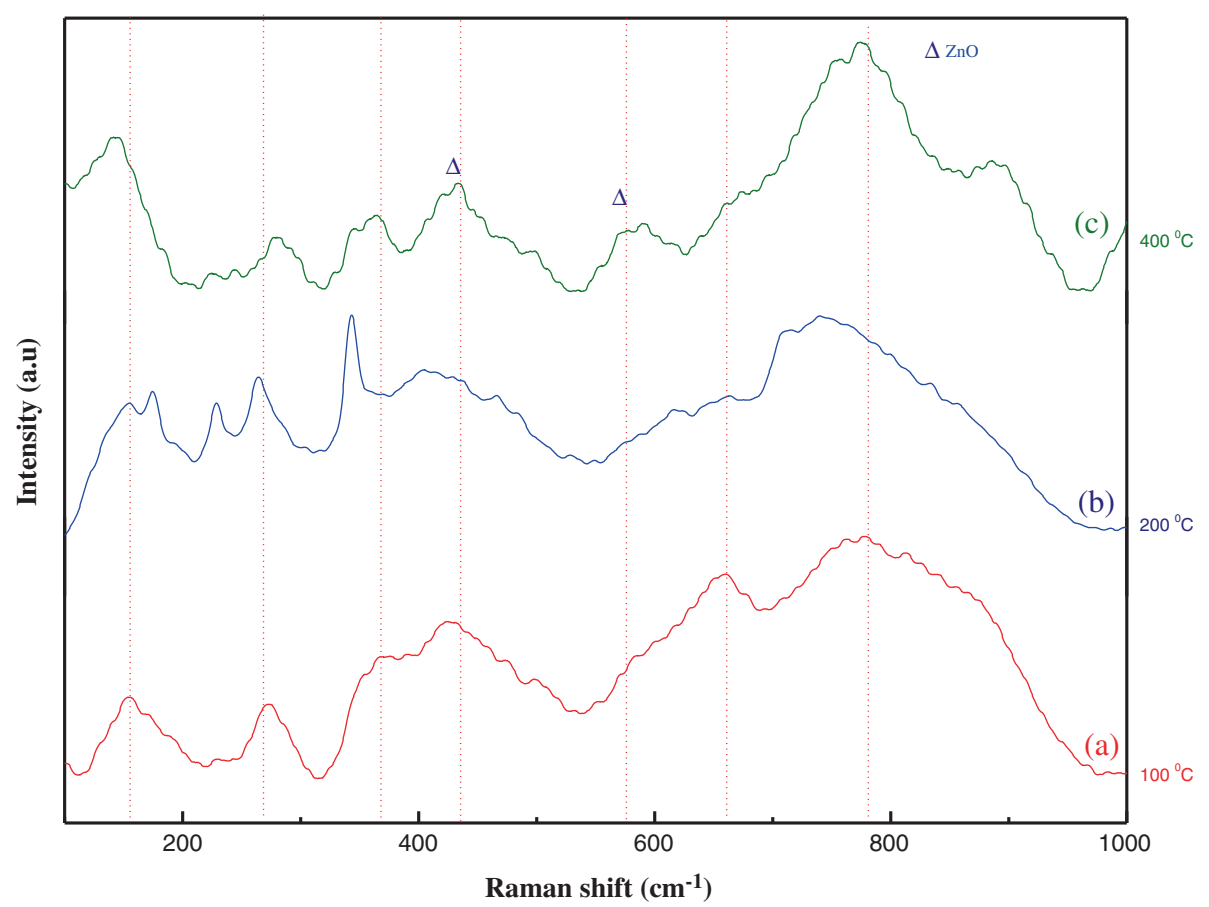

Figure 5. Raman Spectra of zinc titanate powders treated at (a) $100^{\circ} \mathrm{C} / 24 \mathrm{~h}$, (b) $200^{\circ} \mathrm{C} / 2 \mathrm{~h}$, and (c) $400^{\circ} \mathrm{C} / 2 \mathrm{~h}$.

$143 \mathrm{~cm}^{-1}\left(\mathrm{~B}_{1 \mathrm{~g}}\right), 441 \mathrm{~cm}^{-1}\left(\mathrm{E}_{\mathrm{g}}\right), 610 \mathrm{~cm}^{-1}\left(\mathrm{~A}_{1 \mathrm{~g}}\right)$ and $826 \mathrm{~cm}^{-1}\left(\mathrm{~B}_{2 \mathrm{~g}}\right)$ were assigned to rutile $\mathrm{TiO}_{2}$ formed in samples calcinated at $1000^{\circ} \mathrm{C} .{ }^{13,38} \mathrm{XRD}$ patterns of the samples taken at these temperatures confirm the presence of cubic $\mathrm{ZnTiO}_{3}$, hexagonal ilmenite $\mathrm{ZnTiO}_{3}$, cubic $\mathrm{Zn}_{2} \mathrm{TiO}_{4}$ and rutile $\mathrm{TiO}_{2}$ lattices. Raman peaks of the samples calcined at $600^{\circ} \mathrm{C}$ and $1000^{\circ} \mathrm{C}$ were similar.

The similarity observed in the Raman spectra of the samples calcined at $600^{\circ} \mathrm{C}$ and $1000^{\circ} \mathrm{C}$ can be explained based on the similarity in crystal structures of cubic $\mathrm{ZnTiO}_{3}$ and cubic $\mathrm{Zn}_{2} \mathrm{TiO}_{4}$. Cubic $\mathrm{ZnTiO}_{3}$ has a 


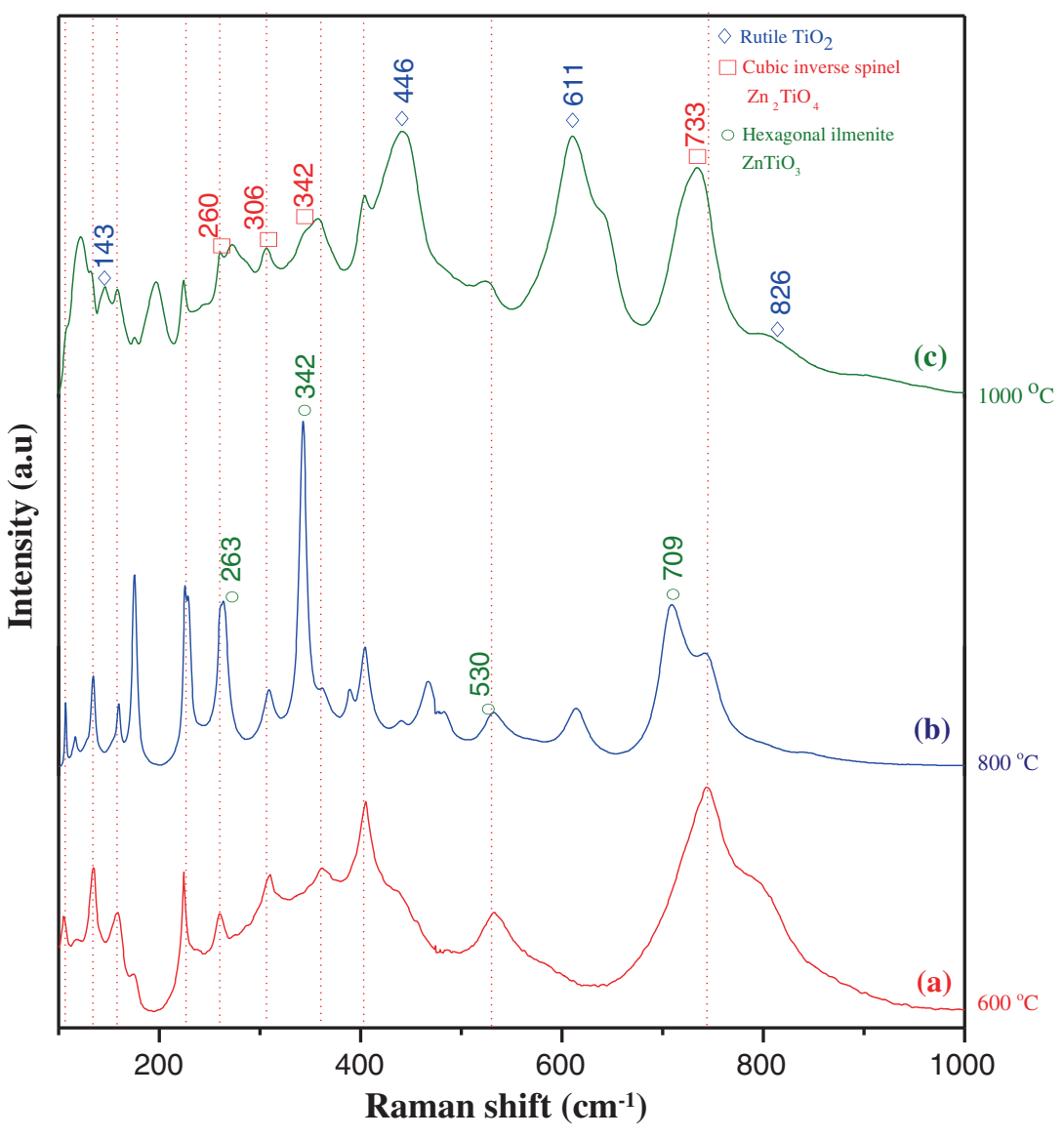

Figure 6. Raman Spectra of zinc titanate powders calcined at (a) $600^{\circ} \mathrm{C} / 2 \mathrm{~h}$, (b) $800^{\circ} \mathrm{C} / 2 \mathrm{~h}$, and (c) $1000^{\circ} \mathrm{C} / 2 \mathrm{~h}$.

defect spinel structure composed of 56 sites represented as $\left(\mathrm{Zn}_{8}\right)^{\mathrm{t}}\left(\mathrm{Zn}_{8 / 3} \square_{8 / 3} \mathrm{Ti}_{32 / 3}\right)^{\circ} \mathrm{O}_{32}$, where $8 \mathrm{Zn}^{2+}$ cations occupy tetrahedral site, while other $8 / 3 \mathrm{Zn}$ cations along with $32 / 3 \mathrm{Ti}^{4+}$ cations occupy octahedral sites and the remaining $8 / 3$ octahedral cation sites are vacant. Similarly cubic inverse spinel $\mathrm{Zn}_{2} \mathrm{TiO}_{4}$ is also composed of 56 sites represented as $\left(\mathrm{Zn}_{8}\right)^{\mathrm{t}}\left(\mathrm{Zn}_{8} \mathrm{Ti}_{8}\right)^{\circ} \mathrm{O}_{32}$, where $8 \mathrm{Zn}^{2+}$ cations occupy tetrahedral sites, while other 8 $\mathrm{Zn}^{2+}$ cations along with $8 \mathrm{Ti}^{4+}$ cations occupy the octahedral sites. ${ }^{12}$ Both cubic $\mathrm{ZnTiO}_{3}$ and cubic $\mathrm{Zn}_{2} \mathrm{TiO}_{4}$ have similar crystal structure and lattice parameters. ${ }^{11}$ From this it can be inferred that the similarity in the Raman peaks as shown in figure 6 may be due to the similarity in the crystal structure and lattice parameters of cubic defect spinel $\mathrm{ZnTiO}_{3}$ and cubic inverse spinel $\mathrm{Zn}_{2} \mathrm{TiO}_{4}$.

\subsection{Optical studies}

Figure 7 shows the diffuse reflectance spectra of zinc titanates calcined at different temperatures recorded in the range of 200 to $800 \mathrm{~nm}$ using pressed $\mathrm{BaSO}_{4}$ powder as reference. For calculating bandgap of semiconducting metal oxides, the relation between the absorption edge and photon energy (hv) can be written as $(\alpha \mathrm{h} v)^{\mathrm{n}}=\mathrm{A}\left(\mathrm{h} \nu-\mathrm{E}_{\mathrm{g}}\right)$, where $\mathrm{A}$ is absorption constant, $\mathrm{n}=2$ for direct bandgap and $1 / 2$ for indirect bandgap. ${ }^{18}$ To the best of our knowledge, bandgap variation in zinc titanates with respect to crystallite size is not yet reported in literature. Metal oxides like $\mathrm{ZnO}$ or $\mathrm{SnO}_{2}$ show a gradual decrease of bandgap energy with increase in calcination temperature and crystallite size. ${ }^{39,40}$ From the figure 7 inset it can be observed that bandgap energies of zinc titanates initially decrease, later increase and finally decrease in the temperature ranges 100 to $300^{\circ} \mathrm{C}, 300$ to $800^{\circ} \mathrm{C}$ and 800 to $1000^{\circ} \mathrm{C}$, respectively. Significant phase transformations were observed from the XRD patterns of the samples calcined at the above mentioned temperature ranges. Samples calcined in the temperature range 100 to $300^{\circ} \mathrm{C}$ were found to be amorphous and showed a red shift of the absorption edge from $336 \mathrm{~nm}$ to $345 \mathrm{~nm}$ and bandgap decreased from $3.69 \mathrm{eV}$ to $3.59 \mathrm{eV}$. In the temperature range of $300^{\circ} \mathrm{C}$ to $800^{\circ} \mathrm{C} \mathrm{ZnO}$ and amorphous zinc titanate phases reacted to form cubic phase $\mathrm{ZnTiO}_{3}$ and showed a gradual blue shift in the absorption edge from $345 \mathrm{~nm}$ to $323 \mathrm{~nm}$ and the bandgap increased from $3.59 \mathrm{eV}$ to $3.84 \mathrm{eV}$. The increase in bandgap may be due 


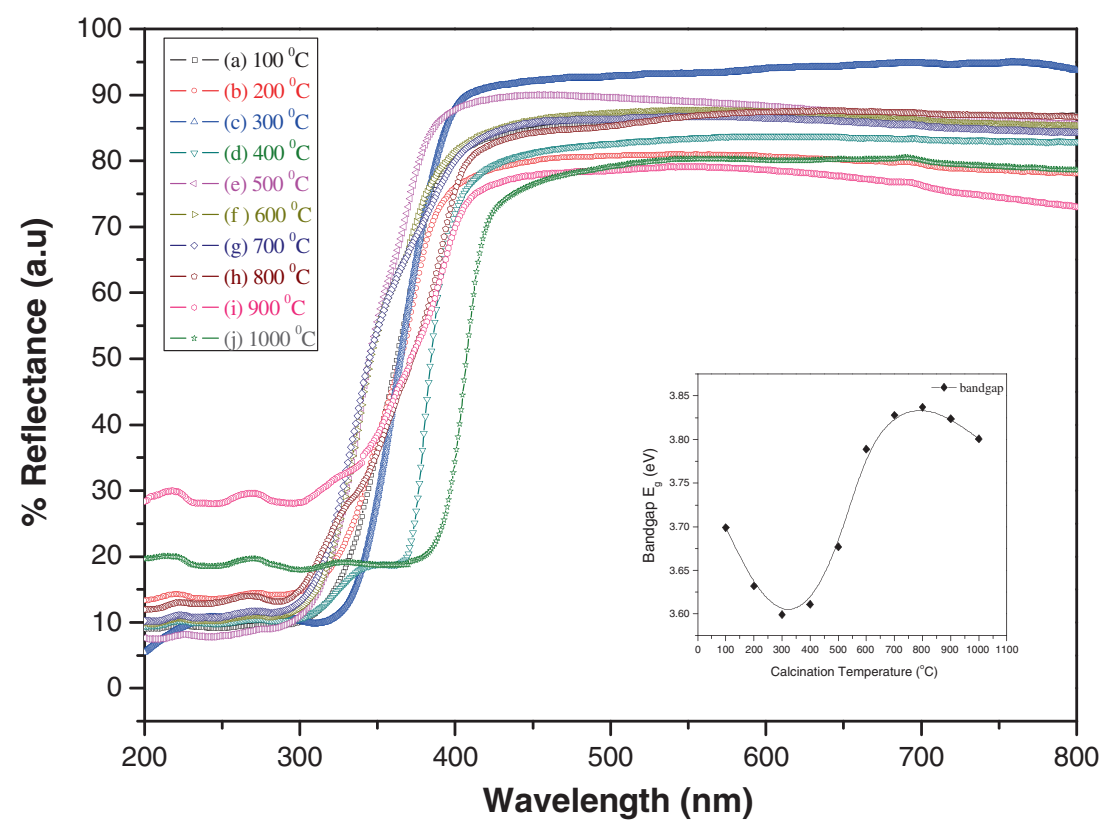

Figure 7. Diffuse reflectance spectra of zinc titanate calcinated at various temperatures. Inset: plot of bandgap $(\mathrm{eV})$ versus calcination temperature $\left({ }^{\circ} \mathrm{C}\right)$.

to the formation and crystallization of $\mathrm{ZnTiO}_{3}$ in the temperature range $300^{\circ} \mathrm{C}$ to $800^{\circ} \mathrm{C}$. Similarly in the calcination temperature range 800 to $1000^{\circ} \mathrm{C}$, hexagonal ilmenite phase $\mathrm{ZnTiO}_{3}$ was formed along with cubic phase $\mathrm{ZnTiO}_{3}$ and finally both phases decomposed to form cubic $\mathrm{Zn}_{2} \mathrm{TiO}_{4}$ and rutile $\mathrm{TiO}_{2}$. Hexagonal $\mathrm{ZnTiO}_{3}$ and cubic $\mathrm{Zn}_{2} \mathrm{TiO}_{4}$ have a lower bandgap than the cubic $\mathrm{ZnTiO}_{3}{ }^{10}$ Decrease in bandgap from $3.84 \mathrm{eV}$ to $3.80 \mathrm{eV}$ in the temperature range of $800^{\circ} \mathrm{C}$ to $1000^{\circ} \mathrm{C}$ may be due to the gradual phase transition from cubic $\mathrm{ZnTiO}_{3}$ to hexagonal $\mathrm{ZnTiO}_{3}$ and final decomposition to $\mathrm{Zn}_{2} \mathrm{TiO}_{4}$ and rutile $\mathrm{TiO}_{2}$.

\section{Conclusions}

Zinc titanate powders were successfully synthesized from $\mathrm{ZnCl}_{2}$ and $\mathrm{TiCl}_{3}$ by a simple precipitation method followed by calcination. From the thermal analysis a total of $27.83 \%$ weight loss observed from the tentative $\mathrm{ZnTi}(\mathrm{OH})_{6}$ hydroxide or $\mathrm{ZnTiO}_{3} .3 \mathrm{H}_{2} \mathrm{O}$ precursor is in good agreement with the theoretical weight loss of $25.10 \%$ due to loss of water molecules from $\mathrm{ZnTi}(\mathrm{OH})_{6}$ to form $\mathrm{ZnTiO}_{3}$. A new crystalline phase with three broad peaks was observed in samples calcined at $100^{\circ} \mathrm{C} / 24 \mathrm{~h}$. $\mathrm{Zn}_{2} \mathrm{Ti}_{3} \mathrm{O}_{8}$ was observed along with $\mathrm{ZnO}$ at $500^{\circ} \mathrm{C}$. Crystalline pure cubic phase $\mathrm{ZnTiO}_{3}$ was formed at $600^{\circ} \mathrm{C}$. Partial phase transition of cubic $\mathrm{ZnTiO}_{3}$ to hexagonal ilmenite type $\mathrm{ZnTiO}_{3}$ was observed in the temperature range of $700-900^{\circ} \mathrm{C}$. Both cubic and hexagonal ilmenite type $\mathrm{ZnTiO}_{3}$ underwent complete decomposition to cubic $\mathrm{Zn}_{2} \mathrm{TiO}_{4}$ and rutile $\mathrm{TiO}_{2}$ at $1000^{\circ} \mathrm{C}$. The similarity in the Raman spectra of samples calcined at $600^{\circ} \mathrm{C}$ and $1000^{\circ} \mathrm{C}$ may be due to the similarity in the crystal structure and lattice parameters of the cubic defect spinel $\mathrm{ZnTiO}_{3}$ and cubic inverse spinel $\mathrm{Zn}_{2} \mathrm{TiO}_{4}$ observed at the respective temperatures. These phase transitions are well supported by thermal analysis, powder XRD, EDAX, FT-IR and Raman spectroscopy. The optical bandgap was found to vary in the range of $3.59 \mathrm{eV}$ to $3.84 \mathrm{eV}$ with increase in calcination temperature.

\section{Acknowledgments}

The authors thank VIT-SIF for thermal analysis, powder XRD, FT-IR and DRS, and Dr. R.P. Vijayalakshmi, Sri Venkateswara University, Tirupati for Raman spectral data. One of the authors, B. Lokesh thanks VIT University for providing financial support to carry out the present work.

\section{References}

1. Pineda M, Fierro J L G, Palacios J M, Cilleruelo C, Garcia E and Ibarra J V 1997 Appl. Surf. Sci. 1191

2. Pal N, Paul M and Bhaumik A 2011 Appl. Catal., A. 393 153

3. Wu S P, Luo J H and Cao S X 2010 J. Alloys Compd. $\mathbf{5 0 2} 147$

4. Yadav B C, Yadav A, Singh S and Singh K 2013 Sens. Actuators B. 177605 
5. Obayashi H, Sakurai Y and Gejo T 1976 J. Solid State Chem. 17299

6. Wang N, Li X, Wang Y, Hou Y, Zou X and Chen G 2008 Mater. Lett. 623691

7. Darzi S J and Mahjoub A R 2009 J. Alloys Compd. 486 805

8. McCord A T and Saunder H F 1945 U.S Patent 2379019

9. Steinike U and Wallis B 1997 Cryst. Res. Technol. 32 187

10. Jain P K, Kumar D, Kumar A and Kaur D 2010 Opto. Mater. Adv. Mater. 4299

11. Manik S K and Pradhan S K 2006 Physica E 3369

12. Mrazek J, Spanhel L, Chadyron G and Matejec V 2010 J. Phys. Chem. C. 1142843

13. Hou L, Hou Y D, Zhu M K, Tang J, Liu J B, Wang H and Yan H 2005 Mater. Lett. 59197

14. Nolan N T, Seery M K and Pillai S C 2011 Chem. Mater. 231496

15. Chai Y L, Chang Y S, Chen G J and Hsiao Y J 2008 Mater. Res. Bull. 431066

16. Wang C L, Hwang W S, Chang K M, Ko H H, Hisn C S, Huang H H and Wang M C 2011 Int. J. Mol. Sci. 12935

17. Lee Y C and Chen P S 2013 Thin Solid Films. 531222

18. Ramirez E G, Chaparro M M and Angel O Z 2010 Appl. Phys. A. 108291

19. Phani A R, Passacantando M and Santucci S 2007 J. Phys. Chem. Solids. 68317

20. Liu X 2012 Mater. Lett. 8069

21. Liu Z, Zhou D, Gong S and Li H 2009 J. Alloys Compd. 475840

22. Kim H T, Kim S H, Nahm S and Byun J D 1999 J. Am. Ceram. Soc. 823043
23. Cassaignon S, Koelsch M and Jolivet J P 2007 J. Phys. Chem. Solids. 68695

24. Svehla G 1979 In Vogel's Text book of macro and semimicro Qualitative Inorganic Analysis $5^{\text {th }}$ edition (London and New York: Longman) p 272 and 532

25. Zhong S L, Xu R, Wang L, Li Y and Zhang L F 2011 Mater. Res. Bull. 462385

26. Chamberland B L and Silverman S 1979 J. Less. Common. Met. 65 P41

27. Yuan Z, Huang F, Sun J and Zhou Y 2002 Chem. Lett. 31408

28. Sharma Y, Sharma N, Rao G V S and Chowdari B V R 2009 J. Power Sources 192627

29. Lu W and Schmidt H 2005 J. Eur. Ceram. Soc. 25919

30. Yang J and Swisher J H 1996 Mater. Charact. 37153

31. Wang C T and Lin J C2008 Appl. Surf. Sci. 2544500

32. Yamaguchi O, Morimi M, Kawabata H and Shimizu K 1987 J. Am. Ceram. Soc. 70 C-97

33. Li G, Li L, Goates J B and Woodfield B F 2009 J. Am. Chem. Soc. 1278659

34. Zheng M, Xing X., Deng J, Li L, Zhao J, Qiao L and Fang C 2007 J. Alloys Compd. 456353

35. Wang L, Kang H, Xue D and Liu C 2009 J. Cryst. Growth. 311611

36. Jeong T S, Han M S and Youn C J 2004 J. Appl. Phys. 96175

37. Wang Z, Saxena S K and Zha C S 2002 Phys. Review B. 66024103

38. Krylova G, Brioude A, Girard S A, Mrazek J and Spanhel L 2010 Phys. Chem. Chem. Phys. 1215101

39. Huo Y and Hu Y H 2012 Ind. Eng. Chem. Res. 511083

40. Shi L and Lin H 2011 Langmuir 273977 